\title{
ANALISIS STRUKTUR MODAL PADA PERUSAHAAN SEMEN YANG TERDAFTAR DI BURSA EFEK INDONESIA
}

\author{
Dirah Nurmila Siliwadi \\ Fakultas Syariah, Institut Agama Islam Negeri Palopo (IAIN) Palopo \\ Email : dirahsiliwadi@iainpalopo.ac.id \\ Siti Hartati Muliawani \\ Mahasiswa Fakultas Ekonomi Universitas Muslim Indonesia \\ Email : shertati.muliawani@yahoo.com
}

\begin{abstract}
The aim to be achieved in this study is to analyze the capital structure of the Cement companies listed on the Indonesia Stock Exchange. Cement companies listed on the Indonesia Stock Exchange for 3 years namely 2011 to 2013 in setting their capital structure policies tend to use their own capital which is greater than debt capital, this can be seen from the proportion of own capital which is greater than the proportion of debt. The optimal capital structure of 3 years from 2011 to 2013 occurred in 2011, namely when the cost of the weighted average capital of the minimum Cement company.
\end{abstract}

\section{Keywords : Capital, Cement, Stock Exchange}

\begin{abstract}
Abstrak
Tujuan yang ingin dicapai dalam penelitian ini adalah Menganalisis struktur modal pada perusahaan Semen yang terdaftar di Bursa Efek Indonesia. Perusahaan Semen yang terdaftar di Bursa Efek Indonesia selama 3 tahun yaitu tahun 2011 sampai tahun 2013 dalam menetapkan kebijakan struktur modalnya cenderung menggunakan modal sendiri yang lebih besar dari pada modal hutang, hal ini dapat diketahui dari proporsi modal sendiri yang lebih besar dibandingkan proporsi hutang. Struktur modal yang optimal dari 3 tahun dari 2011 sampai tahun 2013 terjadi pada tahun 2011, yaitu pada saat biaya modal rata-rata tertimbang perusahaan Semen minimum.
\end{abstract}

\section{Kata Kunci : Modal, Semen, Bursa Efek.}

\section{PENDAHULUAN}

Dalam menjalankan operasional perusahaan, setiap perusahaan memerlukan investasi besar dengan kebutuhan dana yang besar pula agar mampu menghasilkan produk-produk yang berkualitas tinggi sehingga tetap unggul dan dapat bertahan dalam 
persaingan bisnis. Di satu sisi, seringkali perusahaan memiliki keterbatasan dana, sehingga menjadi salah satu faktor yang menghambat pertumbuhan perusahaan menjadi perusahaan besar dan memiliki keunggulan bersaing atas produk-produk yang dihasilkannya. Dalam mengatasi keterbatasan dana itu, perusahaan harus mencari sumber-sumber pendanaan yang dapat menyediakan dana dalam jumlah besar untuk membiayai investasi baru. Persaingan antar dunia usaha juga berpengaruh pada industri ini, sehingga perusahaan dihadapkan pada satu keputusan penting dalam bidang keuangan, yaitu masalah pendanaan dalam rangka pengembangan usaha untuk memenuhi permintaan dan untuk bersaing dengan perusahaan lainnya. Dengan adanya pemenuhan dan penggunaan dana yang seimbang diharapkan perusahaan mampu mengatasi segala bentuk permasalahan yang ada, khususnya yang diakibatkan oleh kondisi makro perusahaan. Masalah pendanaan tidak akan lepas dari sebuah perusahaan yang meliputi seberapa besar kemampuan perusahaan dalam memenuhi kebutuhan dana yang akan digunakan untuk beroperasi dan mengembangkan usahanya. Dalam pelaksanaan dan pengembangan usaha, perusahaan memerlukan modal yang secara umum terdapat dua bentuk dasar pembiayaan pada perusahaan yaitu modal sendiri yang berarti sumber intern dan hutang yang berarti sumber ekstern, (Martono dan Harjito, 2008:169). Menurut Munawir (2003:19) Pengertian modal lebih ditekankan sebagai hak atas bagian yang dimiliki oleh pemilik perusahaan yang ditunjukkan dalam pos modal (modal saham), surplus, dan saldo laba, atau kelebihan aktiva yang dimiliki oleh perusahaan terhadap seluruh utang-utangnya.

Sumber intern yaitu dana yang berasal dari dalam perusahaan adalah pemenuhan kebutuhan modal diambilkan dari dana yang dihasilkan oleh perusahaan sendiri. Sumber intern sering disebut sebagai sumber utama untuk membiayai investasi aktiva tetap atau pengeluaran modal. Namun dana yang berasal dari dalam perusahaan itu sendiri jumlahnya terbatas sekali sehingga tidak cukup untuk memenuhi kebutuhannya. Oleh karena itu, perusahaan berusaha mencari tambahan dana yang berasal dari sumber dana ekstern yaitu dana dari luar perusahaan dengan cara meminjam kepada kreditur atau melalui pasar modal. Dalam kenyataannya bank tetap 
menjadi tumpuan pembelanjaan perusahaan. Struktur modal merupakan perimbangan antara hutang jangka panjang dengan modal sendiri, (Martono dan Harjito, 2008:169). Struktur modal diukur menggunakan tiga indikator, yaitu leverage, debt to equity, dan collateralizable assets. Leverage mencerminkan penggunaan sumber dana yang berasal dari utang jangka panjang (modal asing) yang menimbulkan beban tetap bagi perusahaan, seperti beban bunga. Nilai dari indikator ini ditentukan menggunakan long-term debt to total assets ratio (Sugeng, 2009:41). Struktur modal merupakan perbandingan atau imbalan pendanaan jangka panjang perusahaan yang ditunjukkan oleh perbandingan hutang jangka panjang terhadap modal sendiri. Pendanaan dalam arti luas meliputi semua aktivitas perusahaan yang berkaitan dengan usaha mendapatkan dana yang dibutuhkan oleh perusahaan beserta usaha untuk menggunakan dana tersebut seefisien mungkin. Untuk memperoleh modal tersebut, perusahaan harus membayar biaya. Biaya tersebut bisa bersifat eksplisit maupun implisit. Bagi dana yang berasal dari hutang maka biaya modalnya mudah diidentifikasikan, yaitu biaya bunga. Sedangkan bagi dana yang berbentuk modal sendiri, biayanya tidak tampak yang biasanya berbentuk keuntungan yang disyaratkan. Salah satu tugas manajer keuangan adalah menentukan struktur modal yang tepat, yaitu biaya modal minimal yang dapat menghasilkan tingkat return on equity yang tinggi. Struktur modal merupakan masalah yang penting bagi perusahaan, karena baik buruknya struktur modal akan mempunyai efek langsung terhadap posisi keuangan perusahaan yang pada akhirnya akan mempengaruhi nilai perusahaan, (Martono dan Harjito, 2008:170). Kesalahan dalam menentukan struktur modal akan mempunyai dampak yang luas terutama dengan besarnya hutang, maka beban tetap yang harus ditanggung oleh perusahaan semakin besar yang akan menambah risiko tidak dapat membayar beban bunga atau angsuran hutang perusahaan.

Keown (2011:149), perusahaan harus memahami komponen-komponen utama struktur modal. Struktur modal yang optimal adalah struktur modal perusahaan yang akan memaksimalkan harga sahamnya. Terlalu banyak utang akan dapat menghambat perkembangan perusahaan yang juga akan membuat pemegang saham berpikir dua kali 
untuk tetap menanamkan modalnya. Penggunaan hutang jangka panjang dimaksudkan untuk meningkatkan profit, hal tersebut dilakukan jika biaya hutang lebih kecil dari biaya modal. Namun, bagi setiap perusahaan tentu berbeda-beda, tergantung karakteristik bisnis dan keberagaman arus kasnya. Perusahaan dengan arus kas yang stabil biasanya memiliki rasio yang lebih tinggi dari rasio kas yang kurang stabil. Trade-off theory dalam struktur modal adalah menyeimbangkan manfaat dan pengorbanan yang timbul sebagai akibat penggunaan hutang, (Brigham dan Houston, 2009:5). Kebijakan struktur modal melibatkan perimbangan (trade-off) antara risiko dengan tingkat pengembalian. Secara ringkas pecking order theory (Brealey dan Myers, 2008:324-325) menyatakan bahwa: Pertama, perusahaan lebih menyukai internal financing (pendanaan dari hasil operasi perusahaan). Kedua, perusahaan mencoba menyesuaikan rasio pembagian dividen yang ditargetkan dengan berusaha menghindari perubahan pembayaran dividen secara drastis. Ketiga, kebijakan dividen yang konstan dengan fluktuasi profitabilitas dan kesempatan investasi yang tidak dapat bisa diduga. Keempat, apabila pendanaan dari luar (external financing) diperlukan, maka perusahaan akan menerbitkan sekuritas paling "aman" terlebih dahulu. Apabila suatu perusahaan dalam memenuhi kebutuhan dananya mengutamakan sumber dari dalam perusahaan maka akan sangat mengurangi ketergantungannya kepada pihak luar. Kebutuhan dana yang meningkat karena pertumbuhan perusahaan yang pesat sehingga dana dari sumber internal digunakan semua maka perusahaan menggunakan dana yang berasal dari luar perusahaan baik dari hutang (debt financing) maupun dengan mengeluarkan saham baru (external equity financing) dalam memenuhi kebutuhan dananya, (Riyanto, 2005:293). Kebijakan mengenai struktur modal melibatkan trade off antara risiko dan tingkat pengembalian. Penambahan hutang dapat memperbesar risiko perusahaan tetapi sekaligus juga memperbesar tingkat pengembalian yang diharapkan. Risiko yang semakin tinggi akibat membesarnya hutang cenderung menurunkan harga saham, tetapi meningkatnya tingkat pengembalian yang diharapkan akan menaikkan harga saham tersebut. Brigham dan Houston (2009:6), besar kecilnya angka rasio struktur modal menunjukkan banyak 
sedikitnya jumlah pinjaman jangka panjang daripada modal sendiri yang diinvestasikan pada aktiva tetap yang digunakan untuk memperoleh laba operasi. Semakin besar angka rasio struktur modal berarti semakin banyak jumlah pinjaman jangka panjang sehingga semakin banyak bagian dari laba operasi yang digunakan untuk membayar beban bunga tetap, dan semakin banyak aliran kas yang digunakan untuk membayar angsuran pinjaman. Hal ini mengakibatkan semakin sedikit jumlah laba bersih sesudah pajak yang akan diterima oleh perusahaan. Salah satu sektor industri yang ada di Bursa Efek Indonesia adalah perusahaan Semen. Alasan memilih sektor industri semen karena seiring dengan pertumbuhan ekonomi dan permintaan semen domestik yang terus meningkat dengan semakin banyaknya sektor properti dan program infrastruktur pemerintah, akan menimbulkan adanya persaingan antar perusahaan sejenis, sehingga perlu lebih diperhatikan lagi bagaimana kinerja di sektor industri semen, khususnya pada kinerja keuangannya agar dapat unggul dari perusahaan sejenis. Untuk menghadapi pertumbuhan dan persaingan yang pesat, perusahaan harus selalu meningkatkan kinerja perusahaan. Dengan mengetahui struktur modal dapat membantu perusahaan Semen dalam mengkombinasikan sumber dana yang ada dengan biaya seminimal mungkin dan menguntungkan. Brigham dan Houston (2009:6), struktur modal adalah susunan atau perbandingan antara modal sendiri dan pinjaman jangka panjang. Oleh karena itu struktur modal merupakan bagian dari struktur keuangan sehingga struktur modal merupakan masalah penting bagi perusahaan terutama bagi manajer keuangan dalam pengambilan keputusan mengenai pembelanjaan perusahaan, karena baik buruknya struktur modal akan berdampak langsung terhadap posisi keuangan perusahaan yang pada akhirnya dapat mempengaruhi nilai perusahaan. Dari uraian tersebut, maka peneliti tertarik untuk membahas masalah struktur modal pada Perusahaan Semen yang terdaftar di Bursa Efek Indonesia. 


\section{ANALISIS STRUKTUR MODAL PERUSAHAAN SEMEN YANG TERDAFTAR DI BURSA EFEK INDONESIA}

Struktur modal adalah perbandingan atau imbangan jangka panjang yang ditunjukkan oleh perbandingan hutang jangka panjang terhadap modal sendiri. Struktur modal berkaitan dengan penentuan bauran pembelanjaan jangka panjang perusahaan. Struktur modal merupakan bagian dari struktur keuangan. Struktur keuangan merupakan kombinasi atau bauran dari segenap pos yang termasuk dalam sisi kanan neraca keungan perusahaan, sedangkan struktur modal merupakan bauran dari segenap sumber pembelanjaan jangka panjang yang digunakan perusahaan.

Tabel 1. Struktur Modal Perusahaan Semen di BEI Tahun 2011-2013

\begin{tabular}{|c|c|c|c|c|c|c|}
\hline $\begin{array}{r}\text { Kode } \\
\text { Saham }\end{array}$ & Tahun & DAR & DER & DTC & TIE & Rata-rata \\
\hline \multirow{3}{*}{ SMCB } & 2011 & 31.26 & 45.48 & 23.11 & 0.91 & 25.19 \\
\hline & 2012 & 30.82 & 44.55 & 26.06 & 1.64 & 25.77 \\
\hline & 2013 & 41.10 & 69.78 & 32.60 & 0.82 & 36.08 \\
\hline \multirow{3}{*}{ INTP } & 2011 & 13.32 & 15.36 & 5.98 & 1.77 & 9.11 \\
\hline & 2012 & 14.66 & 17.18 & 4.73 & 2.38 & 9.74 \\
\hline & 2013 & 13.64 & 15.80 & 3.87 & 2.85 & 9.04 \\
\hline \multirow{3}{*}{ SMGR } & 2011 & 25.67 & 34.53 & 14.76 & 0.47 & 18.86 \\
\hline & 2012 & 31.66 & 46.32 & 19.76 & 0.71 & 24.61 \\
\hline & 2013 & 29.19 & 41.23 & 16.93 & 0.66 & 22.00 \\
\hline \multicolumn{2}{|c|}{$\begin{array}{l}\text { Rata-rata } \\
\text { Perusahaan }\end{array}$} & 25.70 & 36.69 & 16.42 & 1.36 & 180.39 \\
\hline
\end{tabular}

Sumber: Data diolah

Berdasarkan tabel diketahui bahwa struktur modal perusahaan Semen yang terdaftar di Bursa Efek Indonesia selama 3 tahun yaitu tahun 2011 sampai tahun 2013, dilihat dari rata-rata rasio debt to asset ratio (DAR) sebesar $25,70 \%$, rata-rata rasio debt to equity ratio (DER) sebesar 36,69\%, rata-rata the debt in total capitalization (DTC) sebesar 16,42\% dan rata-rata time interest earned (TIE) sebesar 1,36\%. Perusahaan yang memiliki rata-rata struktur modal yang tertinggi adalah perusahaan PT. Holcim Indonesia, Tbk (SMCB) pada tahun 2013 sebesar 36,08 dengan komposisi dengan rasio DAR sebesar 41,10\%, rasio DER sebesar 69,78\%, rasio DTC sebesar 32,60 dan rasio TIE sebesar 0,82\%. 
Kombinasi dari modal sendiri dan utang yang digunakan oleh perusahaan disebut dengan struktur modal. Berdasarkan hasil analisis perhitungan struktur modal yang diukur dengan menggunakan rasio debt to asset ratio (DAR), debt to equity ratio (DER), the debt in total capitalization (DTC) dan time interest earned (TIE) pada perusahaan Semen yang terdaftar di Bursa Efek Indonesia selama 3 tahun terakhir yaitu tahun 2011 sampai tahun 2013, maka dapat jelaskan bahwa:

\section{PT. Holcim Indonesia, Tbk (SMCB)}

Pada tabel 2 merupakan kombinasi dari modal sendiri dan utang yang digunakan oleh perusahaan PT. Holcim Indonesia, Tbk (SMCB) yang terdaftar di Bursa Efek Indonesia selama 3 tahun yaitu periode tahun 2011 sampai tahun 2013.

Tabel 2

Struktur Modal SMCB

\begin{tabular}{|c|c|c|c|c|c|}
\hline \multirow{2}{*}{ Tahun } & \multicolumn{4}{|c|}{ PT. Holcim Indonesia, Tbk (SMCB) } & \multirow{2}{*}{ Rata- } \\
\cline { 2 - 5 } & DAR & DER & DTC & TIE & rata \\
\hline 2011 & 31.26 & 45.48 & 23.11 & 0.91 & 25.19 \\
2012 & 30.82 & 44.55 & 26.06 & 1.64 & 25.77 \\
2013 & 41.10 & 69.78 & 32.60 & 0.82 & 36.08 \\
\hline
\end{tabular}

Sumber: Data diolah

Berdasarkan tabel diatas dapat diketahui bahwa struktur modal perusahaan SMCB dilihat dari rasio debt to asset ratio (DAR) mengalami fluktuasi setiap tahun, hal ini disebabkan karena porsi penggunaan utang dalam membiayai investasi pada aktiva berfluktuasi yang berarti risiko keungan perusahaan juga akan berfluktuasi. Rasio debt to equity ratio (DER) mengalami fluktuasi setiap tahun, hal ini disebabkan karena pembiayaan operasi perusahaan memfokuskan pada penggunaan modal dari luar perusahaan daripada menggunakan modal dari dalam perusahaan berfluktuasi sehingga resiko keuangan yang ditanggung perusahaan juga berfluktuasi.

Rasio the debt in total capitalization (DTC) mengalami peningkatan setiap tahun, hal ini disebabkan karena perusahaan mampu membayar hutang jangka panjangnya dengan menjaminkan modal sendiri yang dimiliki, sehingga risiko keuangan perusahaan rendah. Rasio time interest earned (TIE) mengalami fluktuasi setiap tahun, 
hal ini disebabkan karena kemampuan perusahaan untuk menutup biaya bunga dengan laba sebelum bunga dan pajak berfluktuasi setiap tahun, sehingga rata-rata struktur modal tertinggi terjadi pada tahun 2013 sebesar 36,08\% dengan kombinasi DAR sebesar 41,10\%, DER sebesar 69,78\%, DTC sebesar 32,60\% dan TIE sebesar 0,82\%.

\section{PT. Indocement Tunggal Prakarsa, Tbk (INTP)}

Pada tabel 3 merupakan kombinasi dari modal sendiri dan utang yang digunakan oleh perusahaan PT. Indocement Tunggal Prakarsa, Tbk (INTP) yang terdaftar di Bursa Efek Indonesia selama 3 tahun yaitu periode tahun 2011 sampai tahun 2013.

Tabel 3

Struktur Modal INTP

\begin{tabular}{|c|c|c|c|c|c|}
\hline \multirow{2}{*}{ Tahun } & \multicolumn{4}{|c|}{ PT. Indocement Tunggal Prakarsa, Tbk (INTP) } & \multirow{2}{*}{ Rata- } \\
\cline { 2 - 5 } & DAR & DER & DTC & TIE & rata \\
\hline 2011 & 13.32 & 15.36 & 5.98 & 1.77 & 9.11 \\
2012 & 14.66 & 17.18 & 4.73 & 2.38 & 9.74 \\
2013 & 13.64 & 15.80 & 3.87 & 2.85 & 9.04 \\
\hline
\end{tabular}

Sumber: Data diolah

Berdasarkan tabel diatas dapat diketahui bahwa struktur modal perusahaan INTP dilihat dari rasio debt to asset ratio (DAR) mengalami fluktuasi setiap tahun, hal ini disebabkan karena porsi penggunaan utang dalam membiayai investasi pada aktiva berfluktuasi yang berarti risiko keungan perusahaan juga akan berfluktuasi. Rasio debt to equity ratio (DER) mengalami fluktuasi setiap tahun, hal ini disebabkan karena pembiayaan operasi perusahaan memfokuskan pada penggunaan modal dari luar perusahaan daripada menggunakan modal dari dalam perusahaan berfluktuasi sehingga resiko keuangan yang ditanggung perusahaan juga berfluktuasi.

Rasio the debt in total capitalization (DTC) mengalami penurunan setiap tahun, hal ini disebabkan karena perusahaan tidak mampu membayar hutang jangka panjangnya dengan menjaminkan modal sendiri yang dimiliki, sehingga risiko keuangan perusahaan tinggi. Rasio time interest earned (TIE) mengalami peningkatan setiap tahun, hal ini disebabkan karena ketidakmampuan perusahaan untuk menutup biaya bunga dengan laba sebelum bunga dan pajak rendah setiap tahun, sehingga rata-rata 
struktur modal tertinggi terjadi pada tahun 2012 sebesar 9,74\% dengan kombinasi DAR sebesar 14,66\%, DER sebesar 17,18\%, DTC sebesar 4,73\% dan TIE sebesar 2,38\%.

\section{PT. Semen Gresik (Persero), Tbk (SMGR)}

Pada tabel 4 merupakan kombinasi dari modal sendiri dan utang yang digunakan oleh perusahaan PT. Semen Gresik (Persero), Tbk (SMGR) yang terdaftar di Bursa Efek Indonesia selama 3 tahun yaitu periode tahun 2011 sampai tahun 2013.

\section{Tabel 4}

Struktur Modal SMGR

\begin{tabular}{|l|l|l|l|l|l|}
\hline \multirow{2}{*}{ Tahun } & \multicolumn{4}{|l|}{ PT. Semen Gresik (Persero), Tbk (SMGR) } & \multirow{2}{*}{ Rata-rata } \\
\cline { 2 - 5 } & DAR & DER & DTC & TIE & \\
\hline 2011 & 25.67 & 34.53 & 14.76 & 0.47 & 18.86 \\
2012 & 31.66 & 46.32 & 19.76 & 0.71 & 24.61 \\
2013 & 29.19 & 41.23 & 16.93 & 0.66 & 22.00 \\
\hline
\end{tabular}

Sumber: Data diolah

Berdasarkan tabel diatas dapat diketahui bahwa struktur modal perusahaan SMGR dilihat dari rasio debt to asset ratio (DAR) mengalami fluktuasi setiap tahun, hal ini disebabkan karena porsi penggunaan utang dalam membiayai investasi pada aktiva berfluktuasi yang berarti risiko keungan perusahaan juga akan berfluktuasi. Rasio debt to equity ratio (DER) mengalami fluktuasi setiap tahun, hal ini disebabkan karena pembiayaan operasional perusahaan memfokuskan pada penggunaan modal dari luar perusahaan daripada menggunakan modal dari dalam perusahaan berfluktuasi sehingga resiko keuangan yang ditanggung perusahaan juga berfluktuasi.

Rasio the debt in total capitalization (DTC) mengalami fluktuasi setiap tahun, hal ini disebabkan karena kemampuan perusahaan untuk membayar hutang jangka panjangnya dengan menjaminkan modal sendiri yang dimiliki berfluktuasi setiap tahun, sehingga risiko keuangan perusahaan juga berfluktuasi. Rasio time interest earned (TIE) mengalami fluktuasi setiap tahun, hal ini disebabkan karena kemampuan perusahaan untuk menutup biaya bunga dengan laba sebelum bunga dan pajak berfluktuasi setiap tahun, sehingga rata-rata struktur modal tertinggi terjadi pada tahun 
2012 sebesar 24,61\% dengan kombinasi DAR sebesar 31,66\%, DER sebesar 46,32\%, DTC sebesar $19,76 \%$ dan TIE sebesar $0,71 \%$.

\section{ANALISIS STRUKTUR MODAL YANG OPTIMAL}

Pada struktur modal, biaya modal merupakan komponen utama yang perlu diperhatikan, karena analisis struktur modal yang optimal mampu dicapai, jika biaya modal minimum dan nilai perusahaan meningkat. Analisis struktur modal dapat digunakan untuk mengetahui perkembangan komposisi struktur modal. Dari analisis ini dapat diketahui perbandingan dari tiap-tiap komponen. Pendanaan yang efisien akan terjadi bila perusahaan mempunyai struktur modal yang optimal. Struktur modal yang optimal dapat diartikan sebagai struktur modal yang dapat meminimalkan biaya penggunaan modal keseluruhan atau biaya modal rata-rata sehingga akan memaksimalkan nilai perusahaan. Untuk lebih jelasnya, berikut ini adalah tahapan analisis struktur modal yang optimal pada perusahaan Semen yang terdaftar di Bursa Efek Indonesia selama 3 tahun, yaitu tahun 2011 sampai tahun 2013.

a. Biaya Hutang

Biaya hutang merupakan besarnya biaya yang harus ditanggung oleh perusahaan karena menggunakan dana yang berasal dari hutang untuk menjalankan bisnisnya. Besarnya biaya hutang ini dapat dihitung dengan mengalikan biaya bunga dengan tingkat pajak, dimana biaya bunga diperoleh dari penjumlahan beban bunga dengan total hutang perusahaan. Tingkat pajak yang digunakan untuk menghitung biaya hutang diperoleh dari pengurangan satu dengan hasil perbandingan antara beban pajak dengan laba sebelum pajak penghasilan.

Tabel 5

Biaya Hutang

\begin{tabular}{|l|l|l|l|l|}
\hline $\begin{array}{l}\text { Kode } \\
\text { Saham }\end{array}$ & Tahun & $\begin{array}{l}\text { Biaya Bunga } \\
(\text { Ki })\end{array}$ & $(\mathbf{1 - t )}$ & $\begin{array}{l}\text { Biaya Hutang } \\
(\text { Kd) }\end{array}$ \\
\hline \multirow{4}{*}{ SMCB } & 2011 & 45,932 & 0.56 & 2.56 \\
& 2012 & 45,736 & 0.61 & 2.81 \\
& 2013 & 72,785 & 0.60 & 4.34 \\
\hline
\end{tabular}




\begin{tabular}{|l|l|l|l|l|}
\multirow{3}{*}{ INTP } & 2011 & 24,377 & 0.69 & 1.69 \\
& 2012 & 33,565 & 0.69 & 2.32 \\
& 2013 & 36,471 & 0.68 & 2.50 \\
\hline \multirow{3}{*}{ SMGR } & 2011 & 134,700 & 0.71 & 9.61 \\
& 2012 & 153,183 & 0.72 & 11.09 \\
& 2013 & 170,847 & 0.71 & 12.09 \\
\hline
\end{tabular}

Sumber: Data diolah

Berdasarkan hasil perhitungan dalam tabel 10 diperoleh hasil biaya hutang (cost of debt) dari masing-masing perusahaan Semen yang terdaftar di Bursa Efek Indonesia selama 3 tahun periode tahun 2011 sampai tahun 2013 setiap tahunnya, mengalami peningkatan, hal ini disebabkan karena perusahaan menggunakan dana yang berasal dari hutang daripada modal yang dimilki untuk menjalankan operasionalnya, sehingga biaya hutang yang harus ditanggung oleh perusahaan menjadi besar akibat penggunaan dana dari pinjaman pihak luar.

b. Biaya Modal

Biaya modal (cost of equity) merupakan tingkat pengembalian minimal yang diharapkan investor atas besarnya modal yang ditanamkan pada perusahaan untuk mendanai kegiatan usahanya. Besarnya biaya modal sendiri ditentukan dengan menggunakan pendekatan devident yield yang ditambah dengan tingkat pertumbuhan yang diharapkan. Devident yield diperoleh dari pembagian antara dividen dengan harga saham penutupan. Tingkat pertumbuhan diperoleh dari devident payout dan return on equity (ROE) yaitu devident payout dikali dengan return on equity (ROE). Berikut ini tabel 11 yang menunjukkan hasil perhitungan biaya modal pada perusahaan Semen yang terdaftar di Bursa Efek Indonesia selama 3 tahun periode tahun 2011 sampai tahun 2013. 


\section{Tabel 6}

\section{Biaya Modal}

\begin{tabular}{|l|c|c|c|c|}
\hline $\begin{array}{l}\text { Kode } \\
\text { Saham }\end{array}$ & Tahun & $\begin{array}{c}\text { Divident } \\
\text { Yield }\end{array}$ & Growth & $\begin{array}{l}\text { Biaya } \\
\text { Equity } \\
\text { (Ke) }\end{array}$ \\
\hline \multirow{3}{*}{ SMCB } & 2011 & 3.95 & 331.63 & 3.36 \\
& 2012 & 2.76 & 728.67 & 7.31 \\
& 2013 & 3.96 & 786.59 & 7.91 \\
\hline & 2011 & 1.72 & 686.47 & 6.88 \\
INTP & 2012 & 2.00 & 853.64 & 8.56 \\
& 2013 & 4.50 & $1,442.30$ & 14.47 \\
\hline \multirow{3}{*}{ SMGR } & 2011 & 2.89 & $1,353.00$ & 13.56 \\
& 2012 & 2.32 & $1,220.40$ & 12.23 \\
& 2013 & 2.88 & $1,105.20$ & 11.08 \\
\hline
\end{tabular}

Sumber: Data diolah

Berdasarkan hasil perhitungan dalam tabel 6 diperoleh hasil biaya modal (cost of equityt) dari masing-masing perusahaan Semen yang terdaftar di Bursa Efek Indonesia selama 3 tahun periode tahun 2011 sampai tahun 2013 adalah perusahaan PT. Holcim Indonesia, Tbk, (SMCB) dan PT. Indocement Tunggal Prakarsa, Tbk (INTP) mengalami peningkatan, hal ini disebabkan karena perusahaan menggunakan modalnya dalam berinvestasi tinggi sehingga mengakibatkan tingkat pengembalian atas modal yang diinvestasikan menjadi rendah akibat biaya modal yang terlalu tinggi yang harus di tanggung oleh perusahaan. Sedangkan PT. Semen Gresik (Persero), Tbk (SMGR) mengalami penurunan, hal ini disebabkan karena perusahaan menggunakan modalnya dalam berinvestasi rendah sehingga mengakibatkan tingkat pengembalian atas modal yang diinvestasikan menjadi tinggi, hal ini terjadi akibat biaya modal yang diinvestasikan oleh perusahaan rendah.

\section{c. Struktur Modal}

Struktur modal merupakan jumlah modal secara keseluruhan, yaitu komposisi modal hutang dan modal sendiri dalam perusahaan yang digunakan sebagai modal menjalankan usaha. Besarnya struktur modal dapat dihitung dengan menjumlahkan jumlah hutang dan jumlah modal sendiri. Untuk proporsi hutang dihitung dengan 
membandingkan jumlah hutang dengan jumlah modal keseluruhan. Sedangkan besarnya proporsi modal sendiri diperoleh dari perbandingan antara jumlah modal sendiri dengan jumlah modal keseluruhan. Tabel 7 berikut ini menunjukkan komposisi struktur modal pada perusahaan Semen yang terdaftar di Bursa Efek Indonesia selama 3 tahun periode tahun 2011 sampai tahun 2013.

Tabel 7

Struktur Modal

\begin{tabular}{|c|r|r|r|r|r|r|}
\hline Kode & Tahun & $\begin{array}{l}\text { Proporsi } \\
\text { Mod. } \\
\text { Htg }\end{array}$ & $\begin{array}{l}\text { \% } \\
\text { Modal } \\
\text { Hutang }\end{array}$ & $\begin{array}{l}\text { Proporsi } \\
\text { Mod. } \\
\text { Sdri }\end{array}$ & $\begin{array}{l}\text { \% } \\
\text { Modal } \\
\text { Sendiri }\end{array}$ & Struktur \\
\hline \multirow{3}{*}{ SMCB } & 2011 & 0.45 & 45.48 & 1.00 & 99.97 & 1.45 \\
& 2012 & 0.45 & 44.55 & 1.00 & 99.96 & 1.45 \\
& 2013 & 0.70 & 69.78 & 1.00 & 99.96 & 1.70 \\
\hline \multirow{3}{*}{ INTP } & 2011 & 0.15 & 15.36 & 1.00 & 99.82 & 1.15 \\
& 2012 & 0.17 & 17.18 & 1.00 & 99.84 & 1.17 \\
& 2013 & 0.16 & 15.80 & 1.00 & 99.87 & 1.16 \\
\hline \multirow{3}{*}{ SMGR } & 2011 & 0.35 & 34.53 & 0.99 & 98.97 & 1.33 \\
& 2012 & 0.46 & 46.32 & 0.95 & 95.50 & 1.42 \\
& 2013 & 0.41 & 41.23 & 0.96 & 95.77 & 1.37 \\
\hline
\end{tabular}

Sumber: Data diolah

Berdasarkan hasil perhitungan dalam tabel 12 diperoleh struktur modal dari masing-masing perusahaan Semen yang terdaftar di Bursa Efek Indonesia selama 3 tahun periode tahun 2011 sampai tahun 2013 setiap tahunnya berfluktuasi. Hal ini disebabkan karena komposisi modal hutang dan modal sendiri dalam perusahaan yang digunakan sebagai modal menjalankan usaha berbeda-beda.

d. Biaya Modal Rata-rata Tertimbang (WACC)

Biaya rata-rata modal tertimbang digunakan sebagai dasar pengukuran untuk menentukan besarnya tingkat biaya modal, dimana WACC menggambarkan tingkat pengembalian yang diharapkan investor dan pemegang saham. Dalam menentukan 
besarnya biaya modal rata-rata tertimbang perhitunganya mencakup proporsi komponen biaya hutang dan biaya modal sendiri serta proporsi struktur modal perusahaan baik modal hutang maupun modal sendiri.

Berikut ini tabel 8 yang menunjukkan nilai WACC dari masing-masing perusahaan Semen yang terdaftar di Bursa Efek Indonesia selama 3 tahun periode tahun 2011 sampai tahun 2013, adalah:

Tabel 8

WACC

\begin{tabular}{|c|c|c|c|c|c|}
\hline $\begin{array}{l}\text { Kode } \\
\text { Saham }\end{array}$ & Tahun & $\begin{array}{l}\text { Biaya } \\
\text { Hutang }\end{array}$ & $\begin{array}{l}\text { Biaya } \\
\text { Modal }\end{array}$ & $\begin{array}{l}\text { Struktur } \\
\text { Modal }\end{array}$ & WACC \\
\hline \multirow{3}{*}{ SMCB } & 2011 & 2.56 & 3.36 & 1.45 & 7.38 \\
& 2012 & 2.81 & 7.31 & 1.45 & 11.57 \\
& 2013 & 4.34 & 7.91 & 1.70 & 13.94 \\
\hline \multirow{3}{*}{ INTP } & 2011 & 1.69 & 6.88 & 1.15 & 9.72 \\
& 2012 & 2.32 & 8.56 & 1.17 & 12.04 \\
& 2013 & 2.50 & 14.47 & 1.16 & 18.12 \\
\hline \multirow{3}{*}{ SMGR } & 2011 & 9.61 & 13.56 & 1.33 & 24.50 \\
& 2012 & 11.09 & 12.23 & 1.42 & 24.73 \\
& 2013 & 12.09 & 11.08 & 1.37 & 24.54 \\
\hline
\end{tabular}

Sumber: Data diolah

Berdasarkan hasil perhitungan dalam tabel 8 diperoleh Biaya rata-rata modal tertimbang (WACC) dari masing-masing perusahaan Semen yang terdaftar di Bursa Efek Indonesia selama 3 tahun periode tahun 2011 sampai tahun 2013 setiap tahunnya berfluktuasi. Untuk lebih menilai struktur modal yang optimal pada perusahaan Semen yang terdaftar di Bursa Efek Indonesia selama 3 periode tahun 2011 sampai tahun 2013, maka struktur modal yang diukur dengan menggunakan rasio DAR, DER, DTC dan TIE dapat dibandingkan dengan struktur modal yang diukur dengan menggunakan nilai WACC. Berikut ini tabel 14 yang menunjukkan perbandingan nilai rasio dengan nilai WACC dari masing-masing perusahaan Semen yang terdaftar di Bursa Efek Indonesia selama 3 tahun periode tahun 2011 sampai tahun 2013, adalah : 


\section{Tabel 9}

DAR, DER, DTC, TIE dan WACC

\begin{tabular}{|l|l|l|l|l|l|}
\hline Tahun & DAR & DER & DTC & TIE & WACC \\
\hline 2011 & 23.42 & 31.79 & 14.62 & 1.05 & 13.87 \\
2012 & 25.71 & 36.02 & 16.85 & 1.58 & 16.11 \\
2013 & 27.98 & 42.27 & 17.80 & 1.45 & 18.87 \\
\hline
\end{tabular}

Sumber: Data diolah

Berdasarkan tabel 9 dapat dilihat bahwa struktur modal perusahaan tertinggi terjadi pada tahun 2013, dimana debt to asset ratio (DAR) perusahaan sebesar 27,98\%, debt to equity ratio (DER) sebesar 42,27\% dan the debt in total capitalization (DTC) sebesar $17,80 \%$. Hal ini mengindikasikan bahwa penggunaan hutang terbesar perusahaan terjadi pada tahun 2013. Besarnya penggunaan struktur modal perusahaan pada tahun 2013 seiring dengan peningkatan penggunaan biaya rata-rata tertimbang sebesar $18,87 \%$ atau paling tinggi dibandingkan dengan tahun-tahun yang lain. Dibandingkan dengan tahun 2011 dimana WACC perusahaan sebesar 13,87\% dan tahun 2012 sebesar $16,11 \%$. Struktur modal perusahaan terendah terjadi pada tahun 2011, dimana debt to asset ratio (DAR) perusahaan sebesar $23,42 \%$, debt to equity ratio (DER) sebesar $31,79 \%$ dan the debt in total capitalization (DTC) sebesar 14,62\%. Hal ini mengindikasikan bahwa penggunaan hutang terendah perusahaan terjadi pada tahun 2011. Rendahnya penggunaan struktur modal perusahaan pada tahun 2011 seiring dengan penurunan penggunaan biaya rata-rata tertimbang sebesar 13,87\% atau paling rendah dibandingkan dengan tahun-tahun yang lain. Dibandingkan dengan tahun 2012 dimana WACC perusahaan sebesar 16,11\% dan tahun 2013 sebesar 18,87\%. Penggunaan komposisi jumlah hutang jangka panjang dan jumlah modal sendiri secara optimal terjadi pada tahun 2011 sehingga biaya modal rata-rata tertimbang berada pada posisi paling rendah. Struktur modal yang optimal dapat dicapai dengan menyeimbangkan keuntungan perlindungan pajak dan biaya modal. Hasil penelitian 
ini didukung oleh pendapat Martono dan Harjito (2008) yang menyatakan bahwa struktur modal yang optimal dapat diartikan sebagai struktur modal yang dapat meminimalkan biaya penggunaan modal keseluruhan atau biaya modal rata-rata tertimbang.

\section{PENUTUP}

\section{KESIMPULAN}

Berdasarkan hasil penelitian dan pembahasan, maka simpulan dalam penelitian ini adalah:

1. Perusahaan Semen yang terdaftar di Bursa Efek Indonesia selama 3 tahun yaitu tahun 2011 sampai tahun 2013 dalam menetapkan kebijakan struktur modalnya cenderung menggunakan modal sendiri yang lebih besar dari pada modal hutang, hal ini dapat diketahui dari proporsi modal sendiri yang lebih besar dibandingkan proporsi hutang.

2. Hasil analisis menyatakan bahwa struktur modal yang optimal dari 3 tahun penelitian yaitu tahun 2011 sampai tahun 2013 terjadi pada tahun 2011, yaitu pada saat biaya modal rata-rata tertimbang perusahaan Semen minimum.

\section{SARAN}

Berdasarkan dari simpulan yang telah dikemukakan, maka saran-saran yang peneliti dapat berikan adalah:

1. Penentuan kebijakan struktur modal, manajemen harus cermat dan lebih berhati-hati, karena akan berdampak sangat luas terhadap keberlanjutan perusahaan.

2. Kebijakan struktur modal menentukan biaya modal perusahaan yang selanjutnya akan menentukan nilai perusahaan karena naik turunnya nilai perusahaan merupakan salah satu faktor utama yang menjadi pertimbangan investor dalam berinvestasi pada perusahaan.

\section{DAFTAR PUSTAKA}

Brealey et al., 2008. Dasar-dasar Manajemen Keuangan Perusahaan. Edisi 5, Erlangga. 
Brigham dan Houston. 2009. Dasar-dasar Manajemen Keuangan. Edisi 10, Jakarta, Penerbit Salemba Empat.

Gautama Billy. 2009. Analisis Struktur Modal Pada Perusahaan Otomotif Yang Go Publik Di Bursa Efek Indonesia. Fakultas Ekonomi Universitas Pembangunan Nasional Veteran Jawa Timur

Hanafi, Mamduh. 2003. Manajemen Keuangan Internasional. Penerbit: BPFE. Yogyakarta.

Handayani, Bestasari Dwi. 2008. Pengaruh Struktur Modal terhadap Nilai Perusahaan pada Perusahaan sedang Bertumbuh yang Berbeda (Theory Agency). UNS, jurnal Bisnis \& Ekonomi, volume 6, edisi 1.

Hartono, 2003, Kebijakan Struktur Modal: Pengujian Trade Off Theory dan Pecking Order Theory (Studi pada Perusahaan Manufaktur yang tercatat di BEJ). Perspektif, Vol.8,No.2, Desember 2003: 249-257.

Hidayati,Laili et al. 2010. Analisis Faktor-faktor Yang Mempengaruhi Struktur Keuangan Perusahaan Manufaktur Yang Go Public di Indonesia. Jurnal Bisnis Strategi. Vol.7,Th.V,Juli.

Horne, James Van and John M. Wachowich. 2008. Prinsip-Prinsip Manajemen Keuangan. Jakarta: Salemba Empat

Husnan, Suad. 2007. Manajemen Keuangan : Teori dan Penerapan (Keputusan Jangka Pendek). BPFE: Yogyakarta.

Keown, J. Arthur, John D. Martin, J. William Petty, David F. Scott, JR. 2011. Manajemen Keuangan, Edisi Kesepuluh, Penerbit PT Indeks

Kodrat Sukardi, David dan Herdinata, Cristian. 2009. Manajemen Keuangan. Edisi pertama, Yogyakarta.

Kusumajaya, Dewa Kadek Oka. Pengaruh Struktur Modal dan Pertumbuhan Perusahaan terhadap Profitabilitas dan Nilai Perusahaan pada Perusahaan Manufaktur di BEI. Universitas Udayana.

Martono \& Agus Harjito, 2008, Manajemen Keuangan, EKONISA, Kampus FE UII, Yogyakarta.

Mahendra, Alfredo. 2011. Pengaruh Kinerja Keuangan terhadap Nilai Perusahaan (Kebijakan Deviden sebagai Variabel Moderating) pada Perusahaan Manufaktur di BEI). Universitas Udayana.

Munawir.2003. Analisis Laporan Keuangan. Penerbit Liberty, Jakarta

Nitisemito, Alex. 2004, Pembelanjaan Perusahaan. Penerbit BPFE, Yogyakarta 
Nuswandari Cahyani. 2013. Determinan Struktur Modal Dalam Perspektif Pecking Order Theory Dan Agency Theory. Dinamika Akuntansi, Keuangan dan Perbankan. Hal: 92 - 102 Vol. 2, No. 1 FE. Univ Semarang.

Riyanto, Bambang. 2005. Dasar-dasar Pembelanjaan Perusahaan. Edisi 4 Cetakan Ketujuh. BPFE UGM. Yogyakarta.

Rodoni, Ahmad dan Indoyama Nasaruddin. 2007. Modul Manajemen Keuangan, Penerbit FEIS UIN, Jakarta.

Saidi. 2004. Faktor-Faktor yang Mempengaruhi Struktur Modal pada Perusahaan Manufaktur Go Public di BEJ Tahun 1997-2002, Jurnal Bisnis dan Ekonomi, Vol. XI.

Sartono Agus. 2012. Manajemen Keuangan Teori dan Aplikasi. Edisi:4, Yogyakarta: BPFE.

Sjahrial, Dermawan. 2008. Manajemen Keuangan, Penerbit Mitra wacana media, Jakarta.

Sugeng, Bambang. 2009. Pengaruh Struktur Kepemilikan dan Struktur Modal terhadap Kebijakan Inisiasi Dividen di Indonesia. Jurnal Ekonomi dan Bisnis, Volume 14.

Warsono, 2003. Manajemen Keuangan Perusahaan. Edisi Kedua, cetakan pertama, UMM Press, Malang

Weston, J. Fred dan Thomas E Copeland., 2006, Manajemen Keuangan, Dialihbahasakan oleh Jaka Warsana., Kibrandoko, Edisi Sembilan, Penerbit Binarupa Aksara, Jakarta

Wijayanti Dyah Ayu Septian. 2013. Analisis Struktur Modal Pada PT. Bank Negara Indonesia (Persero) Tbk. Program Studi Manajemen Fakultas Ekonomi Universitas Muria Kudus. 